\title{
IMPLEMENTATION OF INTEGRAL TELECOMMUNICATION ENVIRONMENT FOR HARMONISED AIR TRAFFIC CONTROL WITH SCALABLE FLIGHT DISPLAY SYSTEMS
}

\author{
Igor Zhukov \\ National Aviation University, Kosmonavta Komarova Ave. 1, 03680 Kiev, Ukraine \\ E-mail:eduicao@nau.edu.ua
}

Received 05 May 2010; accepted 01 October 2010

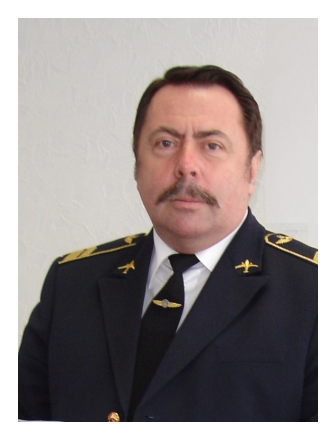

Igor ZHUKOV, Dr Sc Eng

Education: 1972 - Kiev Institute of Civil Aviation Engineers, Ukraine.

Awards: honored inventor of Ukraine, orders and medals of Ukraine.

Research interests: research and development in increasing efficiency of hardware and software computational structure for solving problems in real time.

Publications: author of more than 325 publications.

Present position: director of Computer Technologies Institute.

\begin{abstract}
Creation of digital a telecommunication environment requires the integration of satellite and wideband wireless communication facilities into a single telecommunication system and development of hardware and software for formation and transmission of multimedia traffic in real time for harmonised air traffic control with scalable flight display systems.

Given article is devoted to integral telecommunication environment for navigation and communication with fundamentally new flight display systems.
\end{abstract}

Keywords: telecommunication environment, multimedia traffic, media objects, specialized software, interface.

\section{Introduction}

The 'free-flier operation' mode adopted by the International Civil Aviation Organization (ICAO) requires a significant increase in the capacity of airfield areas and more stringent requirements for flight safety (Глобальный... 2003; Материалы... 2003). The key aspect for solving this problem is significant modification of existing communication and navigation systems with increase in the accuracy of the flight path. This requires digital communication (using satellite and wideband wireless communication), without which the problem of automation process control is difficult to solve (Andrews et al. 2007; Жуков 2009; Жуков и др. 2008).

The reason for the introduction of scalable airspace visualisation introduction with aircraft lanes as the basis for effective air traffic management (ATM) is the following: air traffic management and control systems require conceptually new telecommunication systems that provide communication, navigation and surveillance. (Глобальный... 2003).

The purpose of the paper is to disclose the essence of the implementation of new telecommunication systems for communication and navigation with wideband wireless communications (WWC) (Бабак $u$ дp. 2004; Жуков 2009). WiMAX WWC parameters are the following:

- range $100 \mathrm{~km}$,

- multimedia traffic (MMT) digital data transmission rate $50 \mathrm{Mbps}$,

- $\quad$ aircraft position accuracy $5 \mathrm{~m}$

with two-way signal velocity of the next-higher order than that of a satellite signal.

Under ICAO requirements the typical option of implementing an airfield area multimedia service that is based on integral telecommunication navigation and communication environment with satellite and wireless 
communication WiMAX facilities implementation is considered (Бабак и др. 2004; Жуков 2009).

\section{The realisation of ICAO standards for navigation and communication system}

The ICAO special committee (FANS) has developed necessary standards and recommended practices (SARPs) concerning CNS/ATM for planning, implementation and operation of telecommunication systems for communication, navigation, and monitoring (Глобальный... 2003).

Many regulations concern both air navigation service (PANS) and facilities which should provide multimedia service (MMS) for harmonized air traffic control in the CNS/ATM system.

The problem of the implementation of an integral aircraft automated control system (IACS) that is based on wideband digital telecommunication has not yet been considered, however.

Moreover, a number of new free-flier operation mode provisions have already been solved (Глобальный... 2003):

- separation and monitoring support (current information about the air space);

- implementation of new radio communication characteristics (RCP) (without complete transition to digital communication yet) and monitoring characteristics (RSP) (scalable flight path system has not yet been implemented).

The analysis performed by the ICAO FANS committee has shown that the transition to new flight control mode has got a number of problems, which are as follows (Материалы... 2003):

- $\quad$ significant limitations of existent direct visibility systems related to low level of radio signal transmission;

- difficulties connected with implementation of CNS/ATM systems and proper operation of these systems in many regions of the world;

- lack of multimedia traffic transmission system (voice, video, text) within air-to-ground digital data exchange that provides integral automated control system (IACS) operation as the single airborne and ground-based systems complex.

It is therefore necessary to give a brief analysis of future new telecommunications, which are both for communication and for navigation and monitoring, and which support air traffic management (CNS/ATM) (Andrews et al. 2007; Глобальный... 2003).

Voice transmission in CNS/ATM systems will be performed only in the initial phase. Transmission will be carried out with the help of existing communication channels in the very high frequency (VHF) band. These VHF-channels will be used for digital data transmission in the nearest future (WiFi and WiMAX technologies) (Andrews et al. 2007; Жуков 2008). New satellite data transmission systems integrated into wideband wireless communication (WiMAX) will also be implemented. These systems will provide global multimedia traffic transmission and monitoring data using the same radio frequency spectrum (Andrews et al. 2007; Бабак $u$ дp. 2004).

Improvement in navigation will come about with the implementation of regional navigation equipment (RNAV) and global navigation satellite system (GNSS) (Бабак $u$ дp. 2004). The navigation capabilities of these systems allow them to be used worldwide and to provide en-route navigation for non-precision landing approach. The GNSS will provide highly integral, highly reactive, highly precise, and all-weather navigation service. Successful implementation of the GNSS will allow aircraft to carry out flights in all types of airspace. For that purpose, it is important to effectively integrate satellite and digital wideband wireless communications (Бабак $и$ др. 2004; Жуков 2009).

Conventional radar modes with phase-in $\mathrm{S}$ mode in terminal areas and continental airspace with high air traffic density will be continuously used. However, the main feature will be characterised by automatic dependent surveillance (ADS), for which new nonstop service methods within the WiMAX technology frameworks will be used. ADS makes it possible for an aircraft to transmit automatically data about its position and other data (for instance, its heading and speed) that are necessary for the flight management system (FMS). ADS monitoring both in ADS-B mode and in WiMAX digital antenna service mode will represent a new digital environment for transmitting and receiving information about aircraft position.

To solve these problems, new telecommunications based on the integration of existent satellite and optical communications with wideband wireless network (WWN) must be implemented (Andrews et al. 2007; Бабак и др. 2004; Жуков 2009).

\section{Harmonised multimedia service manage- ment requirements for flight visualisation scalability and accuracy}

The new CNS/ATM system provides wider automation of all air traffic control functions that were previously performed manually. In this regard WWC (WiMAX) implementation will change the interaction between air traffic controllers and pilots. To solve this problem, the ICAO is developing a multimedia service implementation program for ATM and ATC that should significantly improve all ATM and ATC processes.

The fundamental difference of MMS (within the MPEG-4 and MPEG-6 standards) lies in the fact that visualized objects (flight paths) display related to realtime voice data (Ластовченко $u$ дp. 2006). Besides, MPEG-4 audio-visual scenarios consist of several media objects (MO) that are organized hierarchically and in a scalable way.

Due to the hierarchy, media objects could be created and implemented as follows:

1. Scalable flight path charts.

2. Stylistic figures that determine the cartographic background. 
3. Paths of video objects with explanations to them (video and voice without background).

4. Sound objects as voice related to video objects.

MPEG-4 standardises a lot of media objects (MO) that are compatible both with natural and synthesized types that could be 2-(2-D) or 3-dimensional (3-D).
Figure 1 shows the MMS functional structure of the situational airfield area control centre coded 'video and voice' type, or 'synthetic conversation'. These types of objects are connected with aircraft flight path charts (Жуков и дp. 2006).

Lower flow level

Audio-visual standard samples

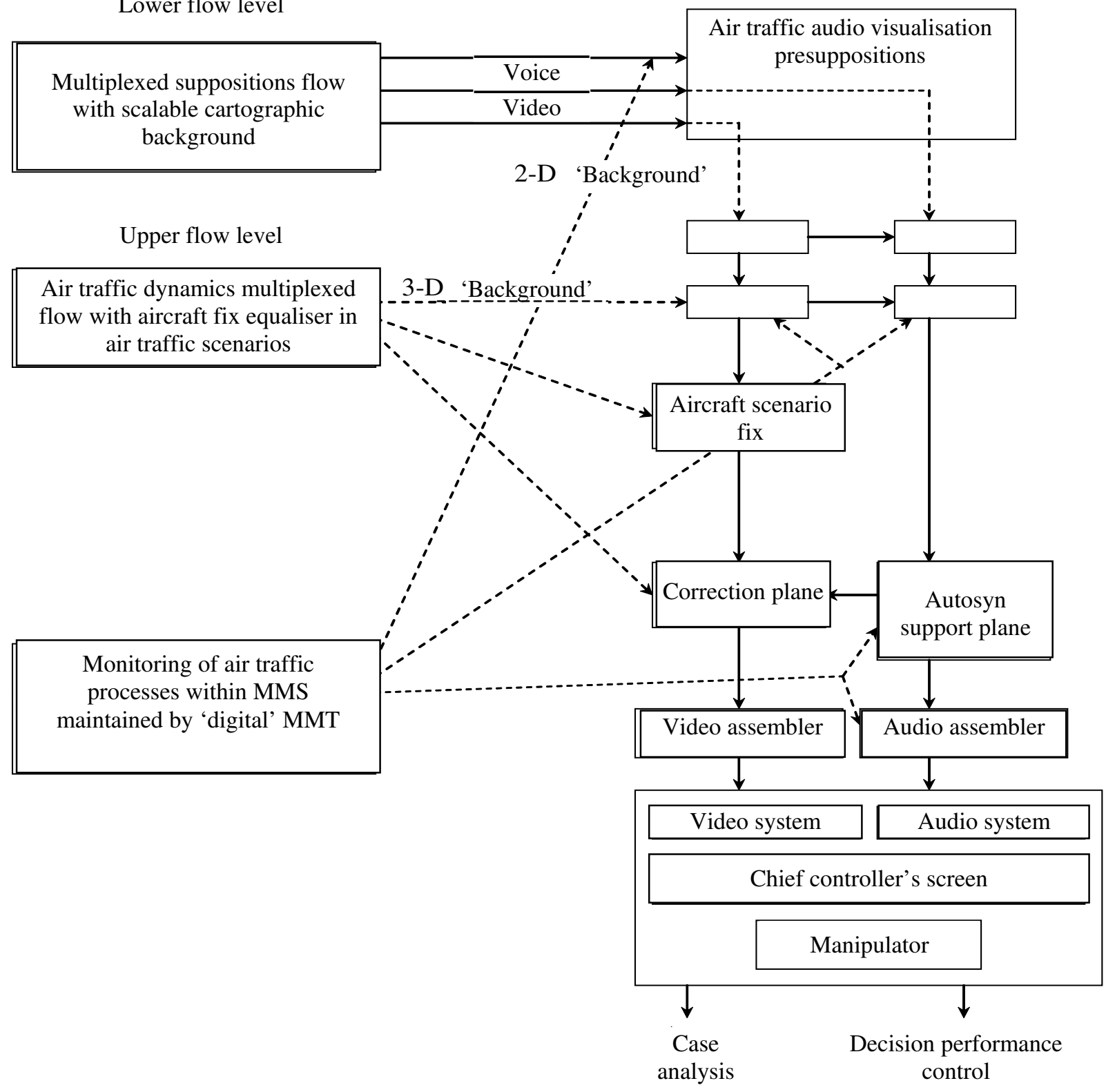

Fig 1. The functional structure of multimedia service control centre (airfield area flight service)

According to the air traffic and aircraft interaction that is displayed, the audio-visual scenario is represented both as the individual objects system and as the integral primitive media objects system. Primitive MO responds to requests in a descriptive tree chart while compound media objects include the entire sub-tree charts.

This MMS functional structure allows air traffic controllers and pilots within the airfield area control centre to consider complex scenarios (aircraft flight paths) with scalable visualization, providing their representations in one of the chosen (scalable) cartographic interface options (Ластовченко $u \partial p$. 2006).

At the same time, the following components of the MMS functional structure should be defined as follows:

1. Transfer platform as the telecommunication environment that within the MPEG-4 standard defines 
transport layers as is usual in the Open Systems Interconnection/Reference Model (OSI/RM). Nowadays, in many cases, adaptation to the specific existing transport layer adjusts both MMT transmission in the MPEG-2 traffic and data transmission within airspace navigation and monitoring.

2. DMIF interface as a structure of transmitted MMT that provides coordination between the application and transport and does not allow the user to control this transport.

This MMS structure is described at two main levels (lower and upper) of the integral telecommunication environment:

- at the lower level an object's descriptors define the relations between the elementary flows that are received for each object (audio and video flows of each videoconferencing participant);

- at the upper level the double format for scenarios describes the parameters of spatial-temporal objects in the scenarios (users can manipulate objects by rearranging them within the scenarios or changing their own parameters in the 3-D virtual environment).

Thus, the main MMS components formed on the basis of the integral telecommunications environment within the MPEG-4 standard provide implementation of the following functions.

1. Location of media objects in the fixed frame of reference.

2. Change in the geometry of media objects in the proper scale.

3. Grouping of primitive media objects for the formation of specified media objects (visualisation of the scripted flight path).

The MPEG-4 standard in visualization mode (this main mode is much more difficult than the formation of sound objects) defines the encoding of the hybrid and video background of natural (pixel-based) figures taken together with synthetic (computer-made) scenarios. Due to this, for example, the interaction of MMS users in realtime is possible. This includes tools and algorithms that support both encoding of pixel-based style figures and video sequences, as well as tools for supporting the compression of the parameters of synthetic 2 and 3-D graphics (Жуков $u$ дp. 2006).

The main requirement is that MMS must adjust data flows (satellite, wireless, radar communication) to media objects for changes measured in their features: the sound, which animates the scenario dynamics, and more importantly the virtual reality visual models.

\section{Integrating telecommunication environ- ment for harmonised air traffic control}

On the basis of switching to a new flight mode, there can be four main components of the new CNS/ATM system. They are communication, navigation, surveillance and air traffic automated management system.

Communication. In the CNS/ATM systems, voice transmission will initially continue to be implemented on existing communication channels in the very high frequency (VHF) band; however, these VHF-channels will be increasingly used for digital data transmission. Satellite data and voice transmission that allows providing the global operational area together with data transmission through communication channels in the very high frequency band is also implemented. Secondary surveillance radar (SSR) S mode, which is increasingly used for observation purposes in the airspace with high traffic density, will also allow providing digital data transmission between airborne and ground-based systems. Aviation telecommunication network (ATN) will provide digital data transmission between ultimate users through different 'air-to-ground' and 'ground-to-ground' communication subnets. Regular data transmission for the purposes of ATM will significantly change the nature of the interaction between airborne and ground-based automated control systems and at the same time allow us to realise a lot of new opportunities.

The expected advantages of future telecommunication systems will allow us to implement more direct and effective communication channels between ground and airborne automated control systems (AACS) used in conjunction with communication systems between a pilot and traffic controller. The digital data transmission channel may essentially be regarded as the key element of new ATM concepts aimed at achieving the real advantages of RA MMT.

It is important to note that the effectiveness of the implementation of WWC (WiMAX technology) is achieved when digital antenna arrays (four for every AA) cover an area within a radius of $100 \mathrm{~km}$ at an MMT digital transmission speed up to 50 mps (Жуков 2008).

Navigation. Navigation improvement is the gradual implementation of the area navigation equipment (RNAV) and the global navigation satellite system (GNSS).

The navigational capabilities of these systems are global in nature and provide en-route navigation with non-precision approach in a worldwide manner. In compliance with additional functional systems and procedures, these systems are also expected to provide the most precise landing approach.

GNSS, defined in the Global Air Navigation Plan, provides highly integral, high precision, all-weather navigation service in a worldwide manner. Successful GNSS implementation fully allows aircraft to fly in all types of airspace anywhere in the world (Глобальный... 2003). However, it is not possible to refuse the services of conventional radio navigation aids before the new technologies are proved to insure the required flight safety standards.

Surveillance. In the first stage of new the technologies, the conventional radar modes will be used. Step by step $S$ mode radar will be implemented in terminal areas and continental airspace with high air traffic density. The main peculiarity will be associated with the implementation of automatic dependent surveillance (ADS), however. ADS will enable aircraft to transmit data about its position and other data, such as heading and speed automatically, as well as other useful 
information issued by the flight management system (FMS), using satellite or other communication channels to the air traffic control (ATC) authority, where the aircraft position will be displayed on a screen similar to the ATC display unit. ADS can also be considered an applicated process that actually combines technical communication and navigation systems and by enhancing the level of automation of ground-based systems will significantly improve ATM, especially in oceanic airspace. Software that enables ground-based computers to use these data for conflict detection and resolution directly is currently being developed. This may ultimately lead to ATC clearance coordinated by airborne and ground-based computers with periodic interference or without human intervention.
In terms of the implementation of the new telecommunications for communication, navigation and surveillance systems in compliance with expected improvements, the greatest positive changes are expected to occur in the field of ATM and ATC.

New integral ACS must include ATM, flows of air traffic arrangement (FATA) and airspace management (ASM), and ATM-associated flight operation aspects. Integrated global ATM system should use the opportunities of the new implemented CNS systems on the basis of internationally agreed standards and procedures.

Figure 2 shows the way in which the creation and development of integral telecommunication environment will have an impact on integral ATM and ATC ACS during the implementation of CNS.

Air traffic management requirements

- Flight safety increase due to improvement in accuracy of airspace display systems

- Growth in landing system capacity, airport capacity optimum work load due to introduction of digital communication for effective collective flight management

- More effective use of airspace, higher flexibility, shorter landing intervals due to implementation of unified airport ACS

\begin{tabular}{|c|c|c|}
\hline Communication & Navigation & Surveillance \\
\hline 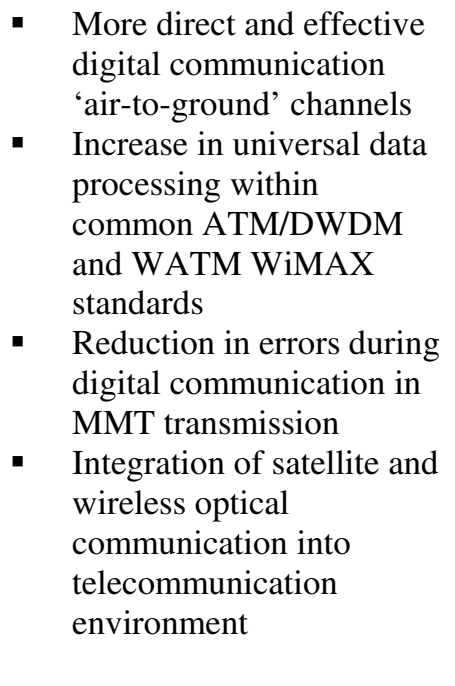 & $\begin{array}{l}\text { - Wideband digital } \\
\text { communication for highly } \\
\text { reliable service through } \\
\text { wireless communication } \\
\text { as the basis of airspace } \\
\text { visualisation } \\
\text { - Improvement in accuracy } \\
\text { of navigation in space and } \\
\text { time due to WiMAX } \\
\text { technology } \\
\text { More effective use of } \\
\text { airports' runways due to } \\
\text { increase in accuracy of } \\
\text { airspace display systems }\end{array}$ & 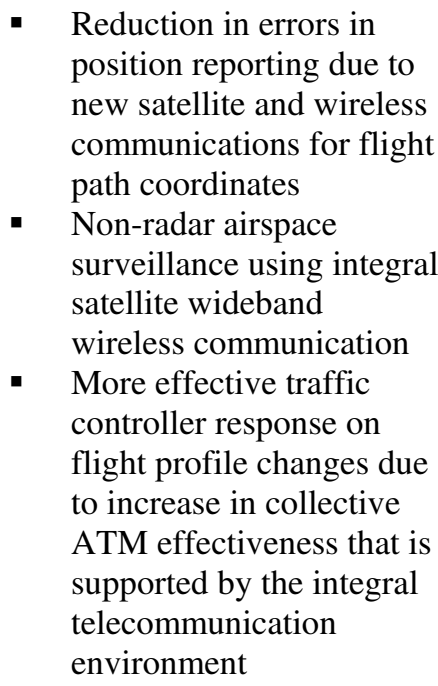 \\
\hline
\end{tabular}

Fig 2. Functional structure of the integral telecommunication environment of the air traffic automated control system

CNS/ATM systems allow data processing and transmission effectiveness to be bettered by improving the surveillance and navigation accuracy through the ADS. This will, inter alia, lead to a reduction in aircraft vertical separation intervals and make it possible to increase the AA airspace capacity.

\section{Conclusions}

A significant increase in the ICAO requirements to improve performance (capacity of airfield areas), which should provide an aircraft new 'free-flier operation' mo- de, determines, respectively, more stringent requirements for air traffic communication, navigation, and surveillance. The main principle in solving this problem is to create a telecommunication environment based on the broadside integrated services digital networks (BISDN).

Based on ICAO requirements imposed for communication, navigation and surveillance of air traffic, the problem has already been solved in many regions. An effectttive multimedia services option for harmonised ATC, which is the foundation of the digital transmission environment, is suggested. 


\section{References}

Andrews, J. G.; Ghosh, A.; Muhamed, R. 2007. Fundamentals of WiMAX: understanding Broadband Wireless Networking, Prentice Hall Communications Engineering and Emerging Technologies Series. 452 p.

Бабак, В. П.; Конін, В. В., Харченко, В. П. 2004. Радіоспутнікова навігація, Техніка. 328 с.

Глобальный аэронавигационный план применительно к системам CNS/ATM. 2003. Монреаль. DOC 9750, AN 963. $325 \mathrm{c}$.

Жуков, И. А. 2009. Новые компьютерные технологии проектирования телекоммуникаций гражданской авиации Украины, Проблеми інформатизації та управління 3(27): 62-71.

Жуков, И. А.; Ластовченко, М. М.; Искренко, Ю. Ю. 2008. Анализ процессов адаптивной коррекции радиоспектра при передаче мультимедийного трафика шумоподобными сигналами, Проблеми інформатизації та управління 2(24): 66-73.

Ластовченко, М.,М.; Федченко, С. В. 2006. Концепция создания специализированного программного обеспечения для системы визуализации навигационной обстановки, Проблеми інформатизаиії та управління 3(21): 93-97.

Материалы ХІ аэронавигационной конвенции. 2003. Монреаль. $118 \mathrm{c}$.

\section{INTEGRALIOS TELEKOMUNIKACNĖS APLINKOS IDIEGIMAS SIEKIANT HARMONIZUOTI SKRYDŽIU VALDYMĄ SU IVAIRAUS PAJĖGUMO SKRYDŽIŲ VALDYMO VAIZDUOKLIŲ SISTEMOMIS}

\section{Zhukov}

S a n tra k a

Skaitmeninei telekomunikacinei aplinkai sukurti reikalingas ne tik palydovinių ir plačiajuostės bevielės telekomunikacinės įrangos integravimas ị vieną telekomunikacinę sistemą, bet taip pat ir techninès bei programinès įrangos vystymas, siekiant sukurti ir perduoti realaus laiko multimedinị eismą tam, kad būtų harmonizuotas skrydžių valdymas su įvairaus pajègumo skrydžių valdymo vaizduoklio sistemomis. Nagrinėjama integrali telekomunikacinè sistema, kuri skirta naujus skrydžio valdymo vaizduoklius naudojančiai navigacijai ir telekomunikacijai.

Reikšminiai žodžiai: telekomunikacinė aplinka, multimedinis eismas, medijos objektai, specializuota programinè ịranga, sąsaja. 